\title{
Pensononowoor
}

2021, vol. 85, 19-29

https://doi.org/10.12657/denbio.085.003

\author{
Julio César Ríos-Saucedo, Eduardo Acuña-Carmona, \\ Jorge Cancino-Cancino, Javier Corral-Rivas, \\ Rigoberto Rosales-Serna, Luis Manuel Valenzuela-Núñez*
}

\section{Allometric models for estimating aboveground biomass in tree sprouts of three dendroenergetic crops}

Received: 17 July 2020; Accepted: 18 January 2021

\begin{abstract}
Recurrent problems have been observed for biomass measurement in tree sprouts, mainly due to differences in patterns of biomass distribution and the bias generated by using models for mature trees. The objective of this research was to evaluate models to estimate aboveground biomass in sprouts from two-year-old stumps of Short Rotation Woody Crops (SRWC) used for energetic purposes.

The study was conducted in Central Chile (Bío-Bío region) under a complete block design and four replications. Three plant species were included: Eucalyptus globulus, E. denticulata, and Acacia dealbata, established in three population densities (5,000, 10,000 and 15,000 trees per ha). Two groups of nonlinear models were used on three independent variables: root collar diameter (squared mean of two dominant stems), height (mean of two dominant stems) and number of epicormic stems.

In the allometric model, the total aboveground biomass and the aboveground biomass by component were explained as the product of the mean square of the root collar diameter, mean height of the two dominant new sprouts and total number of epicormic sprouts as the predictive variable. Values of coefficient of determination $\left(\mathrm{R}^{2}\right)$ ranged from 0.78 to 0.95 and RMSE ranged from 168 to $913 \mathrm{~g}$. The species of E. globulus showed higher RMSE for biomass estimation in the all components except the branch component. The inclusion of dummy variables to identify the differences in each parameter of the models explained the seasonality of the biomass accumulation in tree sprouts at 10, 21, and 31 months of age, improving the model goodness of fit RMSE by $27 \%$.

Accurate prediction of sprouts aboveground biomass was obtained by the models only evaluating the two dominant epicormic sprouts in the stump, avoiding the need of individual sprouts evaluation or using destructive methods for biomass measurement.
\end{abstract}

Keywords: bio-energy, short rotation, Eucalyptus globulus, Eucalyptus denticulata, Acacia dealbata, dummy variables

Addresses: J. C. Ríos-Saucedo, R. Rosales Serna, Instituto Nacional de Investigaciones Forestales, Agrícolas y Pecuarias-Campo Experimental Valle del Guadiana. Carr. Durango-El Mezquital, km 4.5., Durango, México. C. P. 34170; (1) JCR-S https://orcid.org/0000-0002-4797-5126,

(D) RRS https://orcid.org/0000-0002-2185-0907

E. Acuña-Carmona, J. Cancino-Cancino, Universidad de Concepción. Facultad de Ciencias Forestales, Victoria 631, Casilla 160-C, Correo 3, Concepción, Chile;

(1) EA-C https://orcid.org/0000-0002-3029-6805, (1) JC-C https://orcid.org/0000-0001-5821-9249

J. Corral-Rivas, Universidad Juárez del Estado de Durango. Facultad de Ciencias Forestales, Río

Papaloapan, Valle del Sur, Durango, México. C. P. 34120.; (1) https://orcid.org/0000-0002-2851-7517

L. M. Valenzuela-Núñez, Universidad Juárez del Estado de Durango. Facultad de Ciencias Biológicas. Laboratorio de Biología y Ecología Forestal. Av. Universidad S/N, Fracc. Filadelfia, Gómez Palacio, México. C. P. 35010, e-mail: luisvn70@hotmail.com; (1) https://orcid.org/0000-0002-3385-3005

*Corresponding author 


\section{Introduction}

The growth of the world's economy presents an important challenge to the future demand of energy. Renewable energy states about $13.3 \%$ of the world's total primary energy, and it is believed that it will play an increasingly important role in energy supplies in both developing and developed societies in the future (Erakhrumen, 2018). Biofuels represent almost $80 \%$ of total renewable energy supplying more energy than nuclear sources, and about four times as much as hydropower, wind, solar, and geothermal energy combined (FAO, 2007). About $75 \%$ of biofuels are derived from wood fuel (Erakhrumen, 2018; FAO, 2007). Short Rotation Woody Crops (SRWC) used for energy purposes are a viable alternative to increase and diversify the country's energy supply (Peña Sandoval, 2010). In Chile, there are approximately 1.8 million hectares of land considered as rainfed soil. This land with serious restrictions for growth (i.e. rainfall is concentrated in 3 or 4 winter months and has a drought period of 7 to 9 months), may be used to cultivate energetic crops using tree species specially adapted for this condition (Santelices et al., 2013).

The establishment of short rotation crops for biomass production could provide environmental and economic benefits to the rural communities, and for society in general (Sawin et al., 2013). Forest biomass is a source of renewable energy that may be sustainably managed (Richardson \& Verwijst, 2007). The sustainability of dendroenergetic crops depends on several factors: the operations and economy of the production of raw materials, the site productivity, and improvements in forestry practices such as thinning young stands, crop tree management or release, and girdling (Richardson \& Verwijst, 2007). Vegetal biomass is generally considered as a green energy source, nevertheless, Choi \& Manousiouthakis (2020) founded that use of biomass as a fuel may result in a higher $\mathrm{CO}_{2}$ atmospheric concentration than fossil carbon burning, depending on the rate of burning and reforestation intensity. Many species are adequate for the production of large volumes of biomass if they are managed as short rotation forestry crops. The most important dendroenergetic taxa worldwide are eucalypts (Eucalyptus globulus, E. nitens, E. denticulata) (Camps \& Marcos, 2002), willows (Salix spp), poplars (Populus spp), paulownia (Paulownia spp) and acacias (Acacia dealbata, A. melanoxylon, A. retinodes). These species are important as dendroenergetic crops due to their high growth rate and easy sprouting (Hoogwijk et al., 2005). This last characteristic has a high relevance because several short rotation cycles may be the result of only one initial establishment, avoiding the need to replant (Sixto et al., 2007).
The short rotation species are cultivated under a scrub-land system, ranging from one to 15 years and a high-density planting. This results in a higher yield per area unit comparing to a single tree planting of the same age as the trunk/stump, where the new sprouts are developing (De-Souza et al., 2016). This should allow for an optimal usage of the natural resources and for an ecological and economical betterment through the implementation of physical and biological knowledge, (Landsberg et al., 1997). To quantify the performance of dendroenergetic crops, certain functions are necessary to estimate the aboveground biomass. In traditional plantations, established for lumber or wood pulp operations, it is common to use allometric models which are based on correlations between biomass and morphological characteristics (basal diameter or area, height, canopy diameter, or canopy volume. In general, this is one of the best options for predicting and quantifying biomass in single tree type plantations (Hauk et al., 2014). However, in a scrub-land system as is the case for dendroenergetic crops, starting with the second crop cycle, many sprouts emerge from each stump forming multiple trunk individuals. Moreover allometric biomass allocation theory predicts that leaf biomass (ML) scaled isometrically with stem (MS) and root (MR) biomass, and thus above-ground biomass (leaf and stem) (MA) and root (MR) scaled nearly isometrically with below-ground biomass (root) for tree seedlings across a wide diversity of taxa. Furthermore, prior studies also imply that scaling constant should vary with species (Cheng et al., 2014). This presents interesting challenges when trying to estimate the total aboveground biomass, or by components when needed.

Acacia dealbata is a large shrub to tall tree with an erect stem usually ranging in height from two$15 \mathrm{~m}$; it often is seen as a spreading shrub but where space allows it has a rounded crown; bark is brown grey to dark grey, often mottled white (due to lichen growth). Eucalyptus denticulata is a tree up to $60 \mathrm{~m}$ high; bark persistent on lower trunk, grey to grey-brown, fibrous-flaky, smooth above, white, grey or yellow, shedding in long ribbons; tolerates poorly drained upland areas; its growth rate is up to $24 \mathrm{~m}^{3} \mathrm{ha}^{-1}$ year $^{-1}$. Eucalyptus globulus varies from a multi-stemmed shrub on exposed sites, to a medium-sized woodland tree up to $20 \mathrm{~m}$ tall, to a very tall tree up to $70-80 \mathrm{~m}$ tall with a large open crown. Hence the interest in conducting this research study on how to evaluate (fit) the models for estimating the aboveground biomass in the new sprouts at the trunk/stump level for Acacia dealbata, Eucalyptus denticulata and Eucalyptus globulus in two years old stumps. It is hypothesized that exponential typical model for biomass estimation in single-stem trees is efficient in sprouting dendroenergetic crops. 


\section{Materials and methods}

\section{Study design}

This research was performed at La Aguada property located at Yumbel commune in the Bio-Bío region $\left(37^{\circ} 11^{\prime} 22.94^{\prime \prime} \mathrm{S}, 7^{\circ} 26^{\prime} 04.08^{\prime \prime} \mathrm{W}\right)$ in August, 2010. The land is sandy, with soils from alluvial provenance, deep and underdeveloped, derived from black volcanic sands, with a basaltic-andesitic origin, with a coarse composition in its profile and moderately coarse on the surface. The climate is sub-humid, annual mean temperature is $19^{\circ} \mathrm{C}$; the annual average rainfall is $1,093 \mathrm{~mm}$ (Novoa et al., 1989).

The test was implemented following a random complete block design with three repetitions. Each segment block was a square of $110 \mathrm{~m}$ per side $\left(12,100 \mathrm{~m}^{2}\right)$, conformed by four quadrants, each consisting of nine study plots of $18 \mathrm{~m}$ on each side $\left(324 \mathrm{~m}^{2}\right)$. Each study plot, in turn, constituted a $0.4 \mathrm{~m}$ wide buffer zone to prevent the fringe effect and a square core of 30 useful stumps in order to observe and evaluate the growth of the crop. Each quadrant included nine treatments, which are generated from the combination of three species (Acacia dealbata, Eucalyptus denticulata, Eucalyptus globulus) in three plantation densities $(5,000,10,000$ and 15,000 trees ha). Each quadrant corresponded to one of four cutting frequencies (every one, two, three and four years, starting with the first intervention when the crop was two years old. (Fig. 1). It was assumed all observations are independent to make formulas easier in implementation.

\section{Measurement of the variables}

The quadrant has harvested in December 2012, corresponding to a bi-annual cutting frequency. As of yet, three measurements have been carried out with the purpose of evaluating the population dynamics of the new sprouting and the aboveground biomass production in this quadrant: October 2013, September 2014 and September 2015. Each time, the number of new sprouting and of adventitious sprouts at each stump was registered. The type of new sprouting was determined based on its physical characteristics and position on the stump. Those that sprouted on the crown of the trunk/stump and in a horizontal position were identified as adventitious and those better joined to the mother plant (stump) and in a vertical position were identified as sprouts. For the dendrometric measurements, the two main new sprouting of each stump were identified and each measured for the following: total height, crown diameter, diameter at root collar (DRC) and diameter at breast height $(\mathrm{DBH})$, when the new shoots exceeded the height of $1.3 \mathrm{~m}$.

The data used to develope the aboveground biomass functions were gathered on the same dates the measurements were taken and are the result of a destructive biomass study from three stumps selected. The stumps collected comply with the diametric distribution (D) and total height. These trunks/ stumps were cut at $0.1 \mathrm{~m}$ above ground level and then transported and stored at $4{ }^{\circ} \mathrm{C}$. At the laboratory, the shoots from each stump were separated and counted according to their category and their total height was measured, as well as the diameter along the length of the trunk $(0.10,0.50,1.0$ and $1.30 \mathrm{~m}$ ). Afterwards, the components (stem, branch and leaves) of each new shoot were weigthed in fresh state with a digital scale with a precision of $0.01 \mathrm{~g}$. In order to determine the dry weight, samples were taken from each component of up to $500 \mathrm{~g}$, and then dried in a stove at $105^{\circ} \mathrm{C}$, up to the constant mass (Brown, 1999; Schlegel et al., 2000). Afterwards, a)

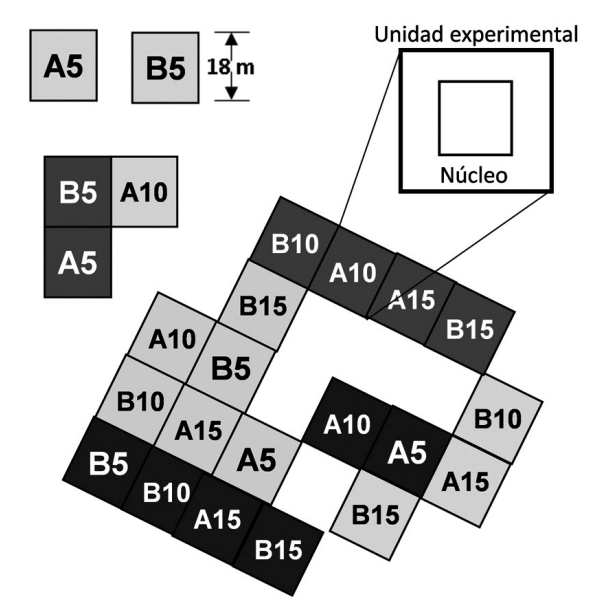

b)

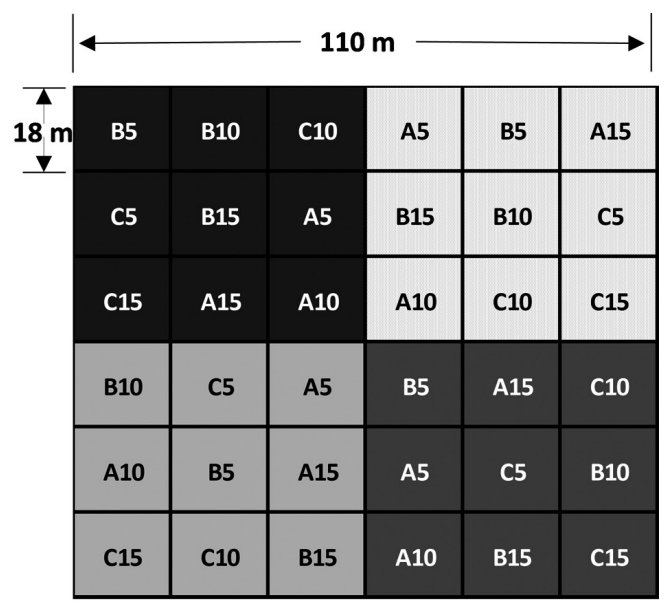

Fig. 1. Description of a trial block. Each color represents a quadrant and a cutting frequency (1, 2, 3 and 4 years); letters represent the species (A - Acacia dealbata, B - Eucalyptus denticulata and C - Eucalyptus globulus) and numbers (5, 10 and 15 for $5,000,10,000$ and 15,00 ind. ha ${ }^{-1}$, respectively) the density of the planting 
from the ratio between dry and wet mass, the total dry aboveground biomass was calculated for each component from each stump. The total aboveground biomass for each stump was obtained by adding the aboveground biomass of all its components. In total, 63 trees of $A$. dealbata, 76 trees of E. denticulata, and 81 trees of E. globulus were analyzed.

Simple linear models have been used in the aboveground biomass modeling of crops on multiple tree trunks (Zeng \& Tang, 2011; Wouokoue Taffo et al., 2018; Malakini et al., 2020); adding the sum of the square value of the diameter at root collar $(D R C)$, the total height of each one of the shoots on the stump as independent variable. To this effect, an allometric model (Model 1) which is commonly used to estimate aboveground biomass was used to test three different sets of predictive variables: i) the product of the diameter squared times the height of the tallest new shoot $\left(D R C^{2} \cdot H\right)$; ii) the product of the average of the diameters squared, times the average height of the two main dominant new shoots $\left(\overline{D R C^{2}} \cdot \bar{H}\right)$; and iii) the product of the average diameters squared times the average height of the two main dominant new shoots, multiplied by the number of new sprouts $\left(\overline{D R C}^{2} \cdot \bar{H} \cdot v p\right)$. Also, two additional models were analyzed (Models 2 and 3 ), consisting of variants of this latter predictive variable. In these last two models, species and age effects were analyzed by incorporating dummy variables: dichotomous and quantitative, their range of values is small; they can take on only two quantitative values, (Jacobs \& Cunia, 1980) (Models 4 and 5).

$$
\begin{gathered}
y_{i}=a_{0} x_{i}^{b_{1}} \\
y_{i}=a_{0}\left(\overline{D R C}^{2} \cdot \bar{H}\right)^{b_{1}}(v p)^{b_{2}} \\
y_{i}=a_{0}\left(\overline{D R C}^{2}\right)^{b_{1}}(\bar{H})(v p)^{b_{2}} \\
y_{i}=a_{0}+\delta_{0_{2}}+\delta_{0_{3}}\left(\overline{D R C^{2}} \cdot \bar{H}\right)^{b_{1}+b_{1_{2}}+b_{1_{3}}(v p)^{b_{2}+b_{2_{2}}+b_{23}}} \\
y_{i}=a_{0}+\delta_{0_{2}}+\delta_{0_{3}}\left(\overline{D R C}^{2}\right)^{b_{1}+\delta_{1_{2}}+\delta_{1_{3}}}(\bar{H})(v p)^{b_{2}+\delta_{2_{2}}+\delta_{2_{3}}}
\end{gathered}
$$

Where: $y_{i}$ is the total aboveground biomass of the ith stump, $x_{i}$ is the predictive variable of the ith stump, $D R C^{2}$ is the average squared root collar diameter of the two dominant shoots on the stump, $H$ is the average height of the two dominant shoots on the stump, $v p$ is the number of new shoots, $a_{0}, b_{1}, b_{2}$ are regression parameters; $\delta_{i_{2}}$ is the dummy variable associated with the age of 21 months, $\delta_{i_{3}}$ is the dummy variable associated with the age of 31 months.

The goodness-of-fit of the models was evaluated using the Root Mean Squared Error (RMSE).

$$
\mathrm{RMSE}=\sqrt{\frac{\mathrm{SS}}{n-p}}
$$

Where, SS is the sum of the residual squares (i.e. $\left.\Sigma\left(y_{i}-\hat{y}_{i}\right)^{2}\right), n$ is the total number of observations and $p$ is the number of parameters in the model.

The Akaike Information Criterion (AIC) was used to select the best models, which is useful when comparing models that vary in the number of parameters. In estimating the amount of information lost by a model, AIC deals with the trade-off between the goodness of fit of the model and the simplicity of the model. In other words, AIC deals with both the risk of overfitting and the risk of underfitting.

$$
A I C=n \ln \left(\frac{S S E}{n}\right)+2 p
$$

Where, $n$ is the total number of observations, $\ln$ is the natural logarithm, SSE is the sum of squares of error $p$ is the number of model parameters.

The adjustments to the models were performed using the NLIN Procedure and the statistical software SAS 9.2 (SAS Institute Inc., 2008).

\section{Results}

The count of new sprouts at 10, 21 and 31 months of growth allowed for the analysis of the population dynamics of new adventitious and type sprouts for each species, as well as, the planting density (Fig. 2). A. dealbata at ten months of growth with 15,000 trees per hectare, registered the highest number of new adventitious sprouts with an average value of eight with low and high extreme values of two and 37 , respectively. However, over time, a significant reduction in this type of new sprouts was registered, i.e. six new sprouts at 21 months and three at 31 months. On the other hand, the number of new sprouts was constant over time, with an average value of four with low and high extreme values of one and six, respectively. E. denticulata at 10 months of growth showed an average value of five and seven new adventitious sprouts in the densities of 10,000 and 15,000 trees per ha respectively. Additionally, a strong variation was observed between stumps with maximum values of up to 25 new sprouts. This feature greatly decreased at 31 months of growth, up to $25 \%$ in adventitious sprouts and $40 \%$ in sprouts in all planting densities. With E. globulus, at 10 months and with 5,000 trees per ha, a larger number of new adventitious sprouts was observed, with an average of eight and a maximum of 36 . At 21 and 31 months a considerable reduction was observed, with an average of three for both types of new sprouts.

In the three species, the total aboveground biomass, as well as by component, was better explained as the product between the average of the squared root collar diameter, the mean height of the two 
dominant new shoots and the quantity of new shoots $(D R C \mid 2 \cdot H \cdot v p)$. For the three species, all the parameters included in the allometric model (Model 1) were significant at $95 \%$ for estimating the total aboveground biomass and by component (Table 1).
RMSE ranged between 168 and 913 g. E. globulus showed a greater RMSE in the estimation of total aboveground biomass and on two of the components (stem and leaves). The statistics for the branches component in A. dealbata and E. denticulata showed a

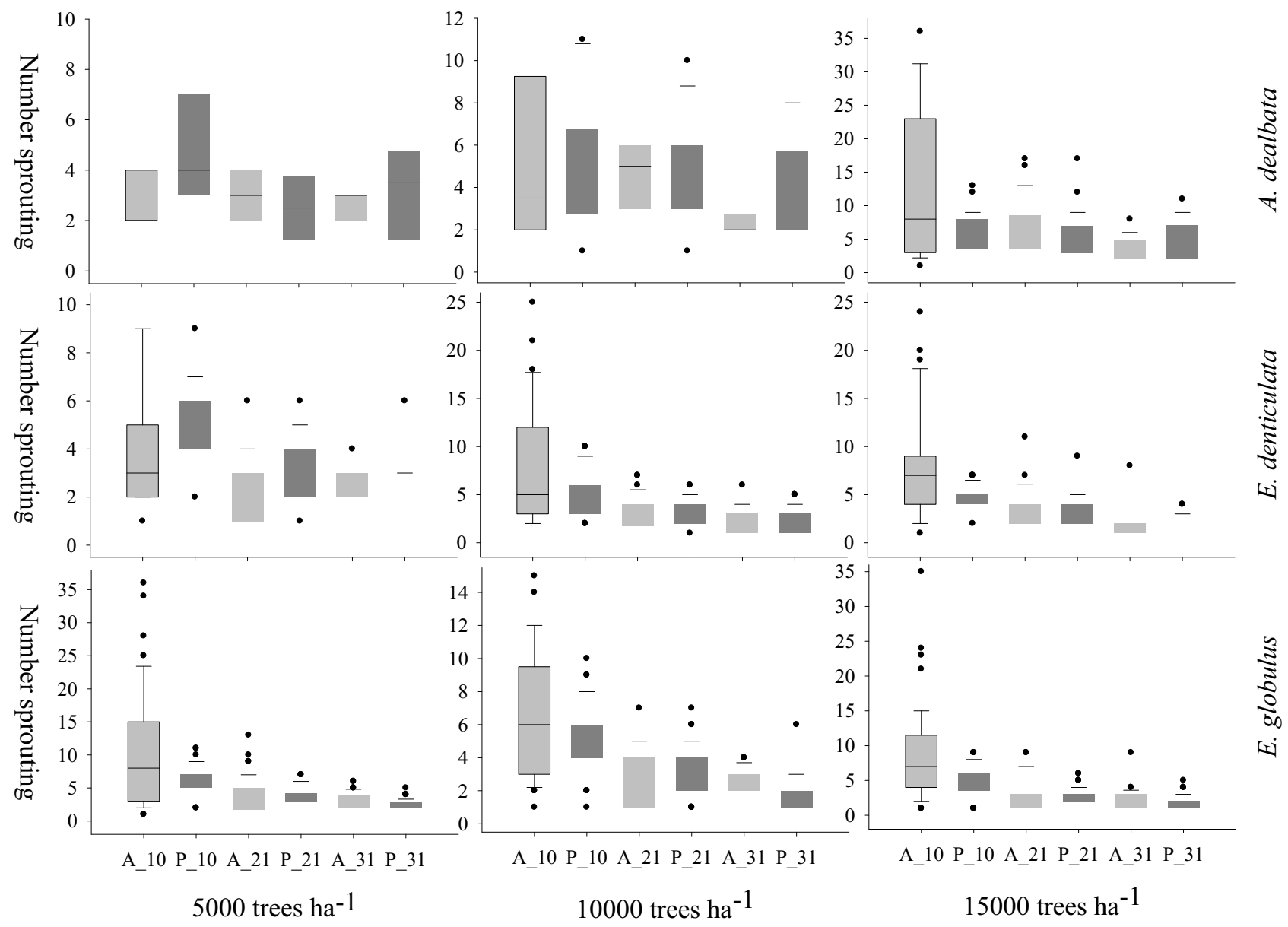

Fig. 2. Boxplot for the number of new adventitious (A) and water (P) sprouts in three ages (10, 21 and 31 months) in stumps of three plant species and planting densities. The rectangle or box boundaries represent $1^{\text {st }}$ and $3^{\text {rd }}$ quartiles, line within the box - median value; whiskers represent range of minimum and maximum without outliers, which are marked by points

Table 1. Estimated parameters and statistical values for goodness-of-fit of the allometric model (Model 1), for estimating total aboveground biomass and for components in shoots, by species

\begin{tabular}{|c|c|c|c|c|c|c|}
\hline Species & Biomass & $\mathrm{n}$ & $a_{0}$ & $b_{1}$ & RMSE & AIC \\
\hline \multirow[t]{4}{*}{ A. dealbata } & Total & 63 & $2.3316^{*}$ & $0.7188^{* *}$ & 690.32 & 825.7 \\
\hline & Stem & 63 & $0.8258^{*}$ & $0.7712^{* *}$ & 485.79 & 781.4 \\
\hline & Branches & 63 & $1.2153^{*}$ & $0.6132^{* *}$ & 185.68 & 660.2 \\
\hline & Leaves & 63 & $0.5221^{*}$ & $0.7166^{* *}$ & 224.64 & 684.2 \\
\hline \multirow[t]{4}{*}{ E. denticulata } & Total & 76 & $5.5198^{*}$ & $0.6892^{* *}$ & 880.85 & 1032.7 \\
\hline & Stem & 76 & $1.8896^{*}$ & $0.7336^{* *}$ & 626.39 & 980.8 \\
\hline & Branches & 76 & $1.6124^{*}$ & $0.6377^{* *}$ & 202.67 & 809.3 \\
\hline & Leaves & 76 & $2.9643^{*}$ & $0.6284^{* *}$ & 290.95 & 864.3 \\
\hline \multirow[t]{4}{*}{ E. globulus } & Total & 81 & $2.0506^{*}$ & $0.7852^{* *}$ & 913.76 & 1106.4 \\
\hline & Stem & 81 & $0.6299^{*}$ & $0.8523^{* *}$ & 758.01 & 1078.1 \\
\hline & Branches & 81 & $0.4804^{*}$ & $0.7389^{* *}$ & 168.98 & 833.0 \\
\hline & Leaves & 81 & $2.6837^{*}$ & $0.6209^{* *}$ & 313.81 & 933.3 \\
\hline
\end{tabular}

Where, $n$ is the sample size, $, b_{1}, b_{2}$ are the regression parameters, RMSE is the Root Mean Squared Error, the asterisks indicate the significance levels, i.e. ${ }^{*} \mathrm{p}<0.05 ;{ }^{* *} \mathrm{p}<0.01$. 


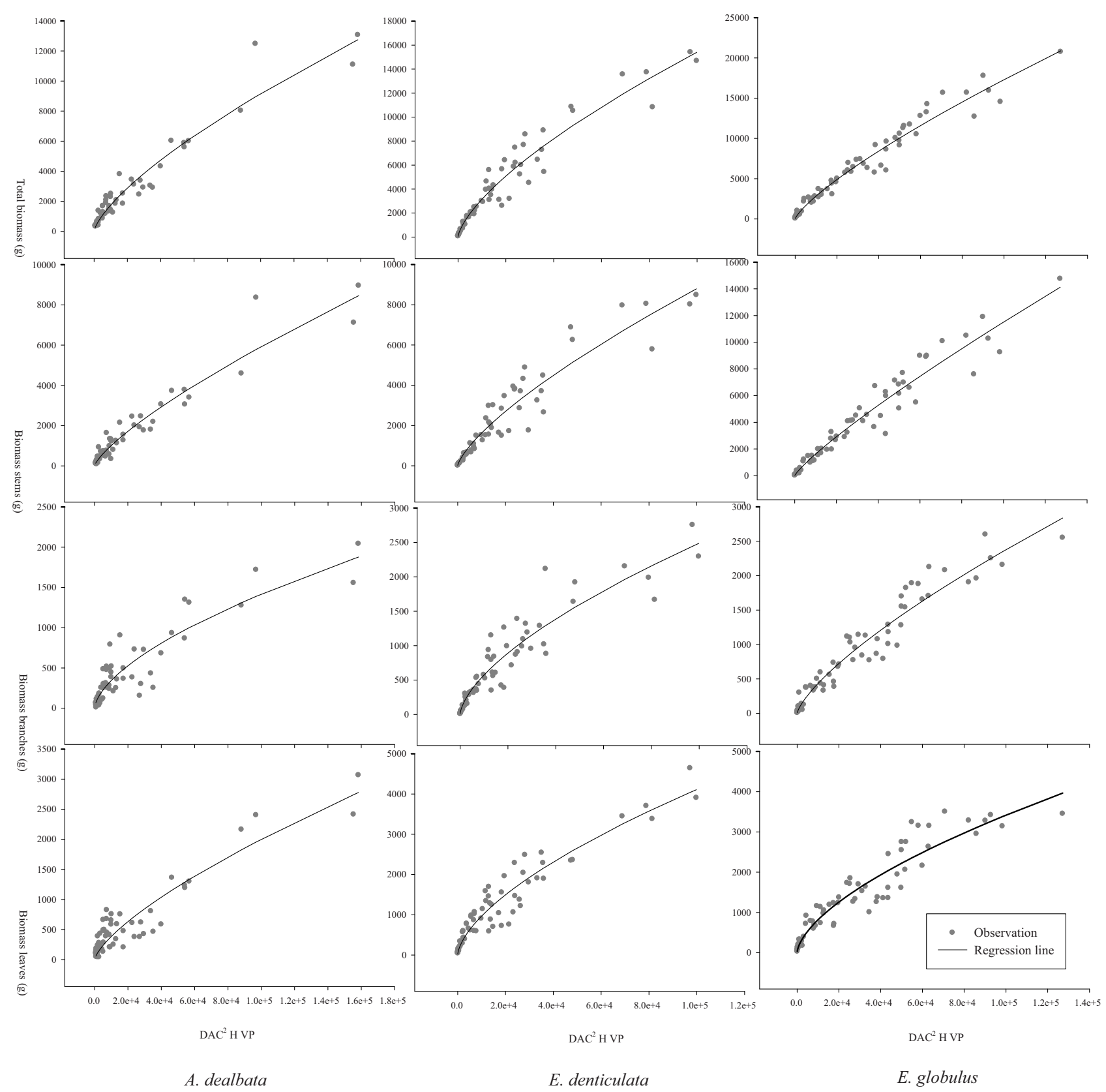

Fig. 3. Dispersion of the data observed from the total aboveground biomass and components (stem, branches and leaves) of the shoots and estimation line of the allometric model evaluated for each species

greater variation, followed by the leaves component (Table 1).

The tendency of the values for total aboveground biomass and by component, with respect to the predictive variable, was similar for the three species. Trends of aboveground biomass and its components, in relation to particular independent variable, were consistent among species studied. This is because in the combined analysis of the aboveground biomass on these three evaluation dates $(10,21$ and 31 months) the passing of time allows the components to be more variable in their aboveground biomass. The foregoing could lead us to conclude that the regression parameters could belong to a single function that would represent the three species and each component. However, in all three species and due to three different ages, the $a_{0}$ coefficient was the one that showed variation in the total aboveground biomass and components (Table 1 and Fig. 3).

Models 2 and 3 provided better adjustments than the allometric model (Model 1). Model 2 used for $A$. dealbata has three regression parameters, where the statistics for goodness-of-fit were similar to the allometric model, but when the models were compared using the AIC, it was less in these models, with values ranging from 656.8 to 812.8 (Table 2).

The evaluated model for estimating total aboveground biomass and by components for the 
Eucalyptus species (Model 3) has a different structure than the one evaluated for $A$. dealbata. This is attributed to the type of plant growth ocurring in the shoots of each genus (Eucalyptus and Acacia). In this model, the statistics for goodness-of-fit were better than those from the allometric model, two of its parameters were of high significance $(\alpha=0.01)$ reducing its RMSE, in total aboveground biomass and its components (stem, branches and leaves) all compared with AIC (Table 3).

The joint analysis of the estimation of aboveground biomass in new shoots for the three evaluation dates 10, 21 and 31 months, was explained including dummy variables in order to identify the differences in each parameter for Models 4 and 5. For A. dealbata the model used for estimating total aboveground biomass and that for leaves component, showed significant differences $(\alpha=0.05)$ on all parameters (Table 4), $\left(a_{0}\right)$ was different at 31 months of age $\left(\delta_{0_{3}}\right)$ and the other two parameters showed differences at age 21 months of age $\left(\delta_{1_{2}}, \delta_{2_{2}}\right)$ (Model 8), yielding six regression parameters within the model. All of them showed significant reduction of the RMSE (Table 4). This may explain why in these types of crops and in this species the leaves component is the one with the greatest variation over time. The stem component only showed differences on the slope at 21 months of age $\left(\delta_{1}, \delta_{2}\right)$ remaining with five regression parameters (Model 9) and the branches component only showed differences in one parameter $\left(b_{2}\right)$ at the age of 21 months $\left(\delta_{2_{2}}\right)$ (Model 10, Table 4 ).

$$
\begin{gathered}
y_{\text {total, leaves }}=a_{0}+\delta_{0_{3}}\left(D R C^{2} \cdot \bar{H}\right)^{b_{1}+\delta_{1_{2}}}\left(v p^{b_{2}+\delta_{2}}\right) \\
y_{\text {stem }}=a_{0}\left(\overline{D R C^{2}} \cdot \bar{H}\right)^{b_{1}+\delta_{1_{2}}}\left(v p^{b_{2}+\delta_{2}}\right) \\
y_{\text {branches }}=a_{0}\left(D R C^{2} \cdot \bar{H}\right)^{b_{1}}\left(v p^{b_{2}+\delta_{2}}\right)
\end{gathered}
$$

With E. denticulata the total aboveground biomass and the stem and branches components only showed significant differences on one of the parameters at 21 months of age $\left(\delta_{2_{2}}\right)$, resulting with four parameters

\begin{tabular}{|c|c|c|c|c|c|c|}
\hline Biomass (y) & $n$ & $a_{0}$ & $b_{1}$ & $b_{2}$ & RMSE & AIC \\
\hline Total & 63 & $1.3238^{*}$ & $0.8050^{* *}$ & $0.6025^{* *}$ & 618.88 & 812.8 \\
\hline Stem & 63 & $0.5095^{*}$ & $0.8436^{* *}$ & $0.6779 * *$ & 461.53 & 775.8 \\
\hline Branches & 63 & $0.8326^{*}$ & $0.6835^{* *}$ & $0.4741^{* *}$ & 179.45 & 656.8 \\
\hline Leaves & 63 & $0.4260^{*}$ & $0.7465^{* *}$ & $0.6805^{* *}$ & 219.69 & 678.1 \\
\hline
\end{tabular}

Table 2. Estimated parameters and statistical data for goodness-of-fit in Model 2, for the estimation of total aboveground biomass and components in shoots of $A$. dealbata

Where, $n$ is sample size, $, b_{1}, b_{2}$ are regression parameters, RMSE is the Root Mean Squared Error, and the asterisks indicate the significance levels, i.e. ${ }^{*} \mathrm{p}<0.05 ;{ }^{* *} \mathrm{p}<0.01$.

\begin{tabular}{|c|c|c|c|c|c|c|}
\hline Biomass (y) & $n$ & $a_{0}$ & $b_{1}$ & $b_{2}$ & RMSE & AIC \\
\hline$E d-$ total & 76 & $5.1300^{*}$ & $0.6549 * *$ & $0.5397^{* *}$ & 678.93 & 994.1 \\
\hline$E d-$ stem & 76 & $1.4636^{*}$ & $0.7448^{* *}$ & $0.4872^{* *}$ & 376.57 & 904.4 \\
\hline$E d$ - branches & 76 & $1.4167^{*}$ & $0.5987^{* *}$ & $0.4937^{* *}$ & 188.62 & 799.4 \\
\hline$E d$ - leaves & 76 & $3.6021^{*}$ & $0.5200^{* *}$ & $0.6759 * *$ & 317.86 & 878.7 \\
\hline$E g-$ total & 81 & $2.0530^{*}$ & $0.7397^{* *}$ & $0.7485^{* *}$ & 807.21 & 1087.3 \\
\hline$E g-$ stem & 81 & $0.7685^{*}$ & $0.8101^{* *}$ & $0.7034^{* *}$ & 558.38 & 1027.6 \\
\hline$E g$ - branches & 81 & $0.4410^{*}$ & $0.6750^{* *}$ & $0.8721^{* *}$ & 176.29 & 840.8 \\
\hline$E g$ - leaves & 81 & $1.9853^{*}$ & $0.5511^{* *}$ & $0.8024^{* *}$ & 354.32 & 953.9 \\
\hline
\end{tabular}

Table 3. Estimated parameters and statistical values for goodness-of-fit for Model 3, for estimating total aboveground biomass and components in shoots of E. denticulata and E. globulus

Where, Ed is E. denticulata, Eg is E. globulus, $n$ is sample size, $, b_{1}, b_{2}$ are the regression parameters, RMSE is the Root Mean Squared Error, and the asterisks indicate the significance levels, i.e. ${ }^{*} \mathrm{p}<0.05 ;{ }^{* *} \mathrm{p}<0.01$.

\begin{tabular}{|c|c|c|c|c|c|c|c|c|c|}
\hline Model & Biomass (y) & $n$ & $a_{0}$ & $\delta_{0_{3}}$ & $b_{1}$ & $\delta_{1_{2}}$ & $b_{2}$ & $\delta_{2}$ & RMSE \\
\hline 8 & Total & 63 & $1.2401^{*}$ & $-0.4575^{*}$ & $0.8893^{* *}$ & $-0.0971^{*}$ & $0.4179 * *$ & $0.2927^{* *}$ & 486.77 \\
\hline 9 & Stem & 63 & $0.5019 *$ & - & $0.8833^{* *}$ & $0.0799 *$ & $0.4504^{* *}$ & $0.4064^{* *}$ & 372.90 \\
\hline 10 & Branches & 63 & $0.5519 *$ & - & $0.7503^{* *}$ & - & $0.2983^{* *}$ & $0.1676^{*}$ & 161.20 \\
\hline 8 & Leaves & 63 & $0.2911^{*}$ & $0.2039 * *$ & $0.9492^{*}$ & $0.1573^{* *}$ & $0.4463^{* *}$ & $0.2646^{*}$ & 178.61 \\
\hline
\end{tabular}

Table 4. Estimated parameters for Models 8, 9 and 10 using dummy variables to estimate total aboveground biomass and of components in new shoots of $A$. dealbata

Where, $y$ is the biomass, is the mean squared root collar diameter of the two dominant water shoots on the stump, is the mean height of the two dominant water shoots on the stump, $\mathrm{vp}$ is the number of new water shoots, $\mathrm{n}$ is the sample size, $\delta_{\mathrm{i}}$ are the dummy variables and $b_{1}, b_{2}$ are the regression parameters, RMSE is the Root Mean Squared Error, and the asterisks indicate the significance levels, i.e. ${ }^{*} \mathrm{p}<0.05 ;{ }^{* *} \mathrm{p}<0.01$. 
Table 5. Estimated parameters for Models 11 and 12 using dummy variables to estimate total biomass and of the components in new shoots of $E$. denticulata

\begin{tabular}{clccccccc}
\hline Model & Biomass $(\mathrm{y})$ & $n$ & $a_{0}$ & $b_{1}$ & $\delta_{1_{2}}$ & $b_{2}$ & $\delta_{2_{2}}$ & RMSE \\
\hline 10 & Total & 76 & $7.4682^{*}$ & $0.6033^{* *}$ & - & $0.6022^{* *}$ & $-0.1058^{*}$ & 637.16 \\
10 & Stem & 76 & $2.3237^{*}$ & $0.6832^{* *}$ & - & $0.5468^{* *}$ & $-0.1245^{*}$ & 346.94 \\
10 & Branches & 76 & $1.9240^{*}$ & $0.5561^{* *}$ & - & $0.5524^{* *}$ & $-0.0969^{*}$ & 185.98 \\
11 & Leaves & 76 & $3.8205^{*}$ & $0.4994^{* *}$ & $0.1405^{*}$ & $0.7960^{* *}$ & $-0.6871^{*}$ & 293.24 \\
\hline
\end{tabular}

Where, $y$ is the biomass, is the mean squared root collar diameter of the two dominant new water shoots on the trunk/stump, is the mean height of the two dominant new water shoots on the stump, $v p$ is the number of new water sprouts, $n$ is the sample size, $\delta$. are the dummy variables, are the regression parameters, RMSE is the Root Mean Squared Error, and the asterisks indicate the significance levels, i.e. ${ }^{*} \mathrm{p}<0.05 ;{ }^{* *} \mathrm{p}<0.01$.

Table 6. Estimated parameters for Model 13 using dummy variables to estimate the total biomass and of its components in new shoots of E. globulus.

\begin{tabular}{|c|c|c|c|c|c|c|c|}
\hline Biomass & $\mathrm{n}$ & $a_{0}$ & $b_{1}$ & $\delta_{1_{3}}$ & $b_{2}$ & $\delta_{2_{3}}$ & RMSE \\
\hline Total & 81 & $1.7305^{* *}$ & $0.8208^{* *}$ & $-0.0687^{* *}$ & $0.4109 * *$ & $0.4539 * *$ & 707.20 \\
\hline Stem & 81 & $0.7127^{*}$ & $0.8677^{* *}$ & $-0.0580^{*}$ & $0.4011^{* *}$ & $0.4536^{* *}$ & 465.76 \\
\hline Branches & 81 & $0.3271^{*}$ & $0.8009^{* *}$ & $-0.0986^{*}$ & $0.4058^{*}$ & $0.5695^{*}$ & 162.88 \\
\hline Leaves & 81 & $1.4540^{*}$ & $0.6632^{* *}$ & $-0.0785^{*}$ & $0.4296^{*}$ & $0.4074^{*}$ & 347.34 \\
\hline
\end{tabular}

Where, $y$ is the biomass, $\left(\mathrm{DRC}^{2}\right)$ is the mean squared root collar diameter of the two dominant new water shoots on the trunk/stump, is the mean height of the two dominant new water shoots on the stump, $v p$ is the number of new water sprouts, $n$ is the sample size, $\delta_{\mathrm{i}}$ are the dummy variables, are the regression parameters, RMSE is the Root Mean Squared Error, and the asterisks indicate the significance levels, i.e. ${ }^{*} \mathrm{p}<0.05 ;{ }^{* *} \mathrm{p}<0.01$.

improving the fit (Table 5). The leaves component yielded five regression parameters, showing significant differences in two of the parameters $\left(b_{1}, b_{2}\right)$ at the same age corresponding to 21 months, $\left(\delta_{2_{2}}\right)$ (Model 11).

$$
\begin{gathered}
y_{\text {total,stem, branches }}=a_{0}\left(\overline{D R C}^{2}\right)^{b_{1}}(\bar{H})\left(v p^{b_{2}+\delta_{2}}\right) \\
y_{\text {leaves }}=a_{0}\left(\overline{D R C}^{2}\right)^{b_{1}+\delta_{1}}(\bar{H})\left(v p^{b_{2}+\delta_{22}}\right)
\end{gathered}
$$

E. globulus also improved the adjustment or fit of its parameters with the incorporation of these types of variables, resulting in a model for estimating total aboveground biomass and its components (stem, branches and leaves), showing significant differences on two of its parameters at 31 months of age $\left(\delta_{1_{3}}, \delta_{2_{3}}\right)$ (Table 6).

$$
y=a_{0}\left(\overline{D R C}^{2}\right)^{b_{1}+\delta_{13}}(\bar{H})\left(v p^{b_{2}+\delta_{2}}\right)
$$

\section{Discussion}

The number of adventitious and sprouts diminished over time due to competition and position of the sprouts on the stump (Fig. 2). Vita et al. (1997) evaluated the response of sprouts on Acacia caven (native to Chile) at different cutting heights from the ground level, registering that the adventitious sprouts were more abundant when the treatment cuts were low, and increased over time. A similar situation was found in this research at the initial development of adventitious new sprouts of $A$. dealbata, although these diminished over time, unlike the sprouts which remained over time. The latter is attributed to the fact that the physiology and sprout production is of the cespitose type, where its new vertical sprouts, as well as the horizontal ones are not hindered in their growth and survival in comparison to eucalyptus where both adventitious and sprouts decrease over time (Fig. 2). Similar results with E. globulus were found by Villegas (2003), reporting that from the multiple new sprouts per bud, over time, only two or three showed rapid growth, affecting others in this manner. Geldres et al. (2004), studied the tendencies of strength and vigor in three Eucalyptus species, concluding that it is feasible to handle E. globulus starting from a sprout. They found that $E$. viminalis displays good sprouting capacity but reaches smaller dimensions and E. regnans was not a good alternative for a scrub land type environment. In our research, both eucalyptus (i.e. E. denticulata and E. globulus) showed similar patterns in the production of new sprouts (Fig. 2).

The allometric model has been used in research of short rotation crops to estimate the aboveground biomass by Liberloo et al. (2006) and Rock (2007) in Populus tremula (L.) $\times$ P. tremuloides (Michx.) (Astria), Vande Walle et al., (2007) in Acer spp., Betula spp., Populus spp and Salix spp., Avohou et al. (2011) in Daniellia oliveri, where researchers measured each shoot as a single stem, while others pruned the stump leaving one or two sprouts, on which the diameter of the stem (DBH) was measured as a predictive variable $(x)$, with the purpose of finding the best fit in the model. For example, Hytönen et al. 
(1995), Ruiz-Peinado et al. (2011), Gómez-García et al. (2014), Gómez-García (2013) and Albert et al. (2014), used allometric models to evaluate biomass production using pseudovolume, which provides single predictor, which avoids effect of variance inflation connected with predictors collinearity. The majority of these studies reported a coefficient of determination $\left(\mathrm{R}^{2}\right)$ greater than 0.85 in the estimation of aboveground biomass (Ríos-Saucedo et al., 2016).

The strategy adopted in this study to estimate aboveground biomass and by component in new sprouts on two year old stumps - without measuring each shoot as an individual tree and without pruning the stump, but only using the two dominant new shoots as predictive variable, the root collar diameter $(D R C)$, the total height $(H)$ and counting the new sprouts $(v p)$, attained good fits with the allometric model on the three species studied, for total aboveground biomass and also for its components (stem, branches and leaves) (Table 1).

The models proved to be better than the allometric model, when utilizing a different number of parameters with a different structure for the predictive variable for the three species (A. dealbata, E. denticulata and E. globulus). Similar results to those reported by Álvarez-González et al. (2005), when they modeled the production of aboveground biomass in Eucalyptus globulus and Pinus pinaster using the simple linear model where; represents the independent variables used, represents the parameters of the model to be estimated and is the error of the model, resulting in different numbers of parameters and predictive variables in the model of the species studied. Reporting a coefficient of determination $\left(\mathrm{R}^{2}\right)$ of up to 0.97 in Eucalyptus globulus and 0.91 in Pinus pinaster in the estimation of aboveground biomass. For the bias correction of the logarithmic transformation, the correction factor proposed by Finney (1941) was applied, concluding that the model is effective for estimating aboveground and undreground biomass in E. robusta, by using the basal area and the circumference of the stump respectively.

Herrero et al. (2014), when explaining the differences between stands planted in scrub-land, used dummy variables to improve the models for estimating total aboveground biomass in E. globulus. Pallardy et al., (2003) studied the clonal variable for poplars using dummy variables to differentiate clones, finding significant differences $(<0.05)$ in the regression parameters, improving the fit of the model.

\section{Conclusions}

The number and type of regrowth decreased significantly after 31 months of growth for all species evaluated, the density of 15,000 trees per hectare must have negative effect or the lowest number of proventitious sprouts. The diameter at root collar height, the average height of the two main new shoots and the total number of new sprouts, are highly correlated in the estimation of total aboveground biomass and of its components (stem, branches and leaves). By precluding the need to measure each new shoot as an individual stem and the need to implement pruning practices for each trunk/stump, it was possible to attain good estimations for aboveground biomass in A. dealbata, E. denticulata and E. globulus, which are used as dendroenergetic crops starting from new sprouts. The allometric model showed a lesser fit in its goodness-of-fit statistics. On the other hand, the specific models per genus were the ones that produced the better statistical fit for estimating total aboveground biomass and by component, and the inclusion of dummy variables helped identify the statistical differences in the parameters of the model for the three evaluation dates.

\section{References}

Albert K, Annighöfer P, Schumacher J \& Ammer C (2014) Biomass equations for seven different tree species growing in coppice-with-standards forests in Central Germany. Scandinavian Journal of Forest Research 29: 210-221. doi:10.1080/02827581 .2014 .910267

Álvarez-González J, Balboa-Murias M, Merino A \& Rodríguez-Soalleiro R (2005) Estimación de la biomasa arbórea de Eucalyptus globulus y Pinus pinaster en Galicia. Recursos Rurais 1: 21-30. https://dialnet.unirioja.es/servlet/articulo? codigo $=3178817$.

Avohou TH, Houehounha R, Glele-Kakai R, Assogbadjo AE \& Sinsin B (2011) Firewood yield and profitability of a traditional Daniellia oliveri short-rotation coppice on fallow lands in Benin. Biomass and Bioenergy 35: 562-571. doi:10.1016/j. biombioe.2010.10.030

Brown S (1999) Guidelines for inventorying and monitoring carbon offsets in forest-based projects. Winrock International, Arlington, Virginia. USA.

Camps M \& Marcos F (2002) Los biocombustibles. Ediciones Mundi-Prensa. Madrid, España.

Cheng D, Ma Y, Zhong Q \& Xu W (2014) Allometric scaling relationship between above- and below-ground biomass within and across five woody seedlings. Ecology and Evolution 4: 3968-3977. doi:10.1002/ece3.1184

Choi SH \& Manousiouthakis VI (2020) On the carbon cycle impact of combustion of harvested plant biomass $v$ s. fossil carbon resources. Computers \& Chemical Engineering 140: 106942. doi:10.1016/j.compchemeng.2020.106942 
De-Souza FC, Gonçalves-dos-Reis G, Ferreira-Reis MG, Garcia-Leite H, Soares-de-Faria R, Pizzol-Caliman J, Alves-Barbosa R \& Rodrigues-de-Oliveira CH (2016) Growth of intact plants and coppice in short rotation eucalypt plantations. New Forests 47: 195-208. doi:10.1007/s11056-015-9509-1

Erakhrumen AA (2018) Wood biomass as a major source of energy in Sub-Sahara African region: implications for sustained research and education in agroforestry technologies: Research for Development in Forestry, Forest Products and Natural Resources Management (ed. by JC Onyekwelu, VAJ Adekunle \& DO Oke) Proceedings of the 1st Biannual Conference of the Forests and Forest Products Society of Nigeria, pp. 205-211. Federal University of Technology, Akure, Nigeria.

FAO (2007) State of the world's forests. Food and Agriculture Organization of the United Nations, Rome, Italy.

Finney DJ (1941) On the distribution of a variate whose logarithm is normally distributed. Supplement to the Journal of the Royal Statistical Society 7: 155-161. doi:10.2307/2983663

Geldres E, Schlatter JE \& Marcoleta A (2004) Monte Bajo, opción para tres especies de Eucaliptos en segunda rotación, un caso en la provincia de Osorno, Décima Región, Chile. Bosque 25: 5762. doi:10.4067/S0717-92002004000300006

Gómez-García E, Crecente-Campo F, Tobin B, Hawkins M, Nieuwenhuis M \& Diéguez-Aranda U (2014) A dynamic volume and biomass growth model system for even-aged downy birch stands in south-western Europe. Forestry 87: 165-176. doi:10.1093/forestry/cpt045

Gómez-García E (2013) Modelos dinámicos de crecimiento para rodales regulares y su desagregación para la estimación de volúmenes y biomasa. Revista Chapingo. Serie Ciencias Forestales y del Ambiente 19: 337-350. doi:10.5154/r.rchscfa.2012.08.047

Hauk S, Knoke T \& Wittkopf S (2014) Economic evaluation of short rotation coppice systems for energy from biomass-A review. Renewable and Sustainable Energy Reviews 29: 435-448. doi:10.1016/j.rser.2013.08.103

Herrero C, Juez L, Tejedor C, Pando V \& Bravo F (2014) Importance of root system in total biomass for Eucalyptus globulus in northern Spain. Biomass and Bioenergy 67: 212-222. doi:10.1016/j. biombioe.2014.04.023

Hoogwijk M, Faaij A, Eickhout B, de Vries B \& Turkenburg W (2005) Potential of biomass energy out to 2100, for four IPCC SRES land-use scenarios. Biomass and Bioenergy 29: 225-257. doi:10.1016/j.biombioe.2005.05.002

Hytönen J, Saarsalmi A \& Rossi P (1995) Biomass production and nutrient uptake of short-rota- tion plantations. Silva Fennica 29: 117-139. doi:10.14214/sf.a9202

Jacobs MW \& Cunia T (1980) Use of dummy variables to harmonize tree biomass tables. Canadian Journal of Forest Research 10: 483-490. doi:10.1139/x80-079

Landsberg JJ, Prince SD, Jarvis PG, McMurtrie RE, Luxmoore R \& Medlyn BE (1997) Energy conversion and use in forests: An analysis of forest production in terms of radiation utilisation efficiency $(\varepsilon)$ : The use of remote sensing in the modeling of forest productivity (ed. by HL Gholz, K Nakane \& H Shimoda) Kluwer Academic Publishers, Dordrecht, The Netherlands, pp. 273-298. doi:10.1007/978-94-011-5446-8_11

Liberloo M, Calfapietra C, Lukac M, Godbold D, Luo ZB, Polle A \& Ceulemans R (2006) Woody biomass production during the second rotation of a bio-energy Populus plantation increases in a future high $\mathrm{CO}_{2}$ world. Global Change Biology 12: 10941106. doi:10.1029/2003GB002127

Malakini M, Makungwa S, Mwase W \& Maganga AM (2020) Allometric models for estimating aboveand below- ground tree carbon for community managed miombo woodlands: A case of Miyobe village forest area in northern Malawi. Trees, Forests and People 2: 100024. doi:10.1016/j. tfp.2020.100024

Novoa R, Villaseca S, Del Canto P, Rouanet J, Sierra C \& Del Pozo A (1989) Mapa agroclimático de Chile Instituto de Investigaciones Agropecuarias. INIA, Santiago, Chile.

Pallardy SG, Gibbins DE \& Rhoads JL (2003) Biomass production by two-year-old poplar clones on floodplain sites in the Lower Midwest, USA. Agroforestry Systems 59: 21-26. doi:10.1023/A:1026176702075

Peña Sandoval G (2010) Desarrollo energético sustentable para el Chile del bicentenario: Las energías renovables en un contexto de políticas públicas. Fundación Konrad Adenauer, Santiago, Chile.

Richardson J \& Verwijst T (2007) Multiple benefits from sustainable bioenergy systems: Proceedings of a joint workshop of IEA bioenergy task 30 and task 31, Western Australia, Australia, August 2005. Biomass and Bioenergy 31: 599-600. doi:10.1016/j.biombioe.2007.06.024

Ríos-Saucedo JC, Acuña-Carmona E, Cancino-Cancino J, Rubilar-Pons R, Návar-Cháidez JJ \& Rosales-Serna R (2016) Allometric equations commonly used for estimating shoot biomass in short-rotation wood energy species: a review. Revista Chapingo. Serie Ciencias Forestales y del Ambiente 22: 193-202. doi:10.5154/r.rchscfa.2015.05.022 
Rock J (2007) Suitability of published biomass equations for aspen in Central Europe - Results from a case study. Biomass and Bioenergy 31: 299-307. doi:10.1016/j.biombioe.2007.01.003

Ruiz-Peinado R, Rio M \& Montero G (2011) New models for estimating the carbon sink capacity of Spanish softwood species. Forest Systems 20: 176-188. doi:10.5424/fs/2011201-11643

Santelices R, Espinoza S \& Cabrera A (2013) Especies potenciales para la obtención de biomasa con fines energéticos en el secano mediterráneo de Chile. Paper presented at the Tercer Congreso Latinoamericano IUFRO, San José, Costa Rica.

SAS Institute Inc (2008) SAS/STAT 9.2 User's guide. SAS Institute Cary, NC, North Carolina.

Sawin JL, Chawala K, Riahi L, Adib R, Skeen J, Chavez S, Skeen J, Hinrichs-Rahlwes R, Macias Galan E, McCrone A, Musolino E, Mastny L, Sims R, Sonntag-O’Brien V, Sverrisson F \&Martinot E (2013) Renewables 2013. Global status report. Renewable Energy Policy Network for the 21st Century (REN21), Paris, France.

Schlegel B, Gayoso J \& Guerra J (2000) Manual de procedimientos y muestreos de biomasa forestal. Proyecto Medición de la capacidad de captura de carbono en bosques de Chile y promoción en el mercado mundial. FONDEF-UACHINFOR, Valdivia, Chile.
Sixto H, Hernández MJ, Barrio M, Carrasco J \& Cañellas I (2007) Plantaciones del género Populus para la producción de biomasa con fines energéticos: revisión. Forest Systems 16: 277-294.

Vande-Walle I, Van-Camp N, Van-de-Casteele L, Verheyen K \& Lemeur R (2007) Short-rotation forestry of birch, maple, poplar and willow in Flanders (Belgium) I-Biomass production after 4 years of tree growth. Biomass and Bioenergy 31: 267-275. doi:10.1016/j.biombioe.2007.01.019

Villegas I (2003) Manejo de rebrotes de Eucalyptus globulus Labillardiére en el altiplano mexicano. Universidad Autónoma Chapingo. Tesis de Licenciatura, Chapingo, Mexico.

Vita A, Serra MT, Grez I, González M \& Olivares A (1997) Respuesta del rebrote en espino (Acacia caven (Mol.) Mol.) sometido a intervenciones silviculturales en zona árida de Chile. Revista Ciencias Forestales 12-13.

Wouokoue Taffo JB, Fonkou T \& Nguetsop VF (2018) Allometric models to estimate the aboveground biomass of tropical highlands savannahs trees. Cameroon Journal of Experimental Biology 12: 49-56. doi:10.4314/cajeb.v12i1.6

Zeng WS \& Tang S (2011) A new general allometric biomass model. Nature Precedings. doi:10.1038/ npre.2011.6704 